\title{
Assessment of nutritional status and dietary habits of children attendingthe nursery in Sanok
}

\begin{abstract}
Introduction. The state of human health largely depends on environmental factors. Nutrition as one of them is important in the earliest stages of child development. By following the principles of rational nutrition, we provide the child the necessary components that determine its growth and development. By analyzing the relationship between nutrition and health three elements should be taken into account: selection of food, compliance with dietary guidelines and an assessment of the effects of nutrition.

Aim. The research aimed at the assessment of nutritional status and dietary habits of children attending the nursery.

Material and methods. The study was conducted among 92 healthy children aged 10-55 months attending two nurseries in the town of Sanok. In all the children, body mass and height were measured and the values obtained were related to the percentile charts. There was also an original questionnaire survey performed addressed to mothers of the children. It provided information on the diets of infants and introducing new complementary products to the diet of children in the first year of life. The results were compared with the nutritional standards for children fed both naturally and artificially.

Results and conclusions. While assessing the nutritional status of children, it was found that incorrect body mass concerned often overweight and obesity. Mothers too early stopped breast-feeding and introduced formulas to the diet of children. The main food product that caused allergic symptoms of children was cow's milk and its products. Most mothers preparing meals for the children used the prepared food products for infants. On the basis of the obtained results it can be concluded that the introduction of complementary food into the diet of infants in the majority did not meet current dietary recommendations in 2007 . There is a need to take preventive measures carried out by medical personnel addressed to parents/carers on the proper nutrition of their children in the first years of life.
\end{abstract}

Keywords: nutritional status, feeding of infants, complementary foods, allergenic foods.

DOI: $10.1515 /$ pjph-2017-0019

\section{INTRODUCTION}

Nutrition is one of the most important determinants of human health. The diet, particularly in the early stages of the child's life, affects the body metabolism, the endocrine system, the immune system, and the food composition determines the intestinal microflora that is important in digestion [1]. Proper nutrition is not only connected with the proper quantitative and qualitative composition of the products, but it is also an important element of prophylaxis of many diseases that are common in later stages of life. The environmental, socio-economic, cultural, or psychological determinants of the choice of a proper diet are determined. Parent's knowledge of rational child nutrition is important, and the adopted and practiced way of feeding has a significant impact on the anthropometric parameters and the biological, psychological and social development of the child. Particularly, in infant feeding, both the needs arising from the dynamic development of the body at that time and the consequences of ongoing dietary errors are to be taken into account.

\section{AIM}

The aim of the study was to evaluate the nutritional status and feeding of infants in infancy.

\section{MATERIAL AND METHODS}

The study was conducted in the group of 92 children ( 47 boys $-51.10 \%$ and 45 girls, $-48.90 \%$ ) in the age between 10 and 55 months (mean age of the examined population 33.84 months) attending two local government nurseries in the city of Sanok. The first step was to perform one-time anthropometric measurements of body weight and height, which were referenced to centiles for age and sex. The following criteria were used to interpret the results: weight appropriate for height (range between 25 and 75 centiles), excess weight - tendency to overweight (75 to 90 centiles), overweight (over 90 to 97 centiles), obesity (over 97 centiles); weight loss (under 25 to 10 centiles), weight loss (10 to 3 centiles), significant weight loss (less than 3 centiles) [2-4]. In the second part, the author's questionnaire was used to refer to the mothers of the examined

\footnotetext{
${ }^{1}$ Jan Grodek State Vocational Academy in Sanok, Institute of Medicine, Poland

${ }^{2}$ Pediatrics Clinic, III Chair of Pediatrics, Medical University of Lublin, Poland
} 
children. The questionnaire contained general questions concerning, inter alia, the date of birth, fetal age, general postnatal status, sex, birth weight, mother's age and education, number of children in the family, and adherence to the recommendations of the current infant formula. In the survey questionnaire, new additions were added to the child's diet, i.e. milk, rice and corn meal, gluten-free foods, fish food, soups with vegetables and meat, egg yolks and cottage cheese. Mothers have also made self-assessment on the knowledge of the current infant formula in quantitative and qualitative terms. The statistical part of the work was carried out on the basis of analytical and descriptive methods. For quantitative variables, descriptive statistics were calculated. Standard deviation (SD), mean value (M), maximum (max.) and minimum (min). Chi-square tests, Chi-square tests and Fisher's tests were used to evaluate the dependence of qualitative variables. The number of $\mathrm{p}<0.05$ was considered statistically significant. The analytical part was developed by the method of generalized linear and nonlinear analysis using Statistica program.

\section{RESULTS}

The examined children were in the following age ranges: up to 15 months ( 5 children - 5.\%), from 16 to 25 months (19$21 \%$ ), from 26 to 35 months $(21-23 \%)$, from 36 to 45 months $(34-37 \%), 46$ months and above $(13-14 \%)$. The mean age of the study population was 33.84 months. The children were born in a generally good condition, the average Apgar score in the study population was 9.66 points, they were from gestation (median duration 39.5 weeks) and mean post weight was 3365.59 g. Mothers who had higher education/bachelor's degree were $66(71.70 \%)$, secondary - 22 individuals $(23.90 \%)$ or basic vocational $(4.30 \%$ of the respondents). Most mothers had one child $(n=42)$ or two children $(n=37)$ in the family. The age of mothers ranged between 31 and 35 years (39 women $-42.40 \%)$, 26-30 years $(32-34.80 \%), 21-25$ years $(10-10.90 \%), 36-40$ years $(9-9.80 \%)$, one person under the age of 20 and one over 40 years old. By analyzing the centimeters of body weights and heights, the following results were obtained: weight appropriate for height (between 25 and 75 centiles) 62 persons $-67.39 \%$, excess weight - tendency to overweight (over 75 to 90 centile) $8-8.70 \%$; overweight (over 90 to 97 . centiles) 10 $-10.87 \%$; obesity (over 97 centiles) $2-2.17 \%$; slimness (below 25 to 10 centiles) 7 that is $7.61 \%$; weight loss (less than 10 to 3 centiles) $3-3.26 \%$. The average body weight of the study population was $14.77 \mathrm{~kg}$ and body height was $95.14 \mathrm{~cm}$ (Figure 1).

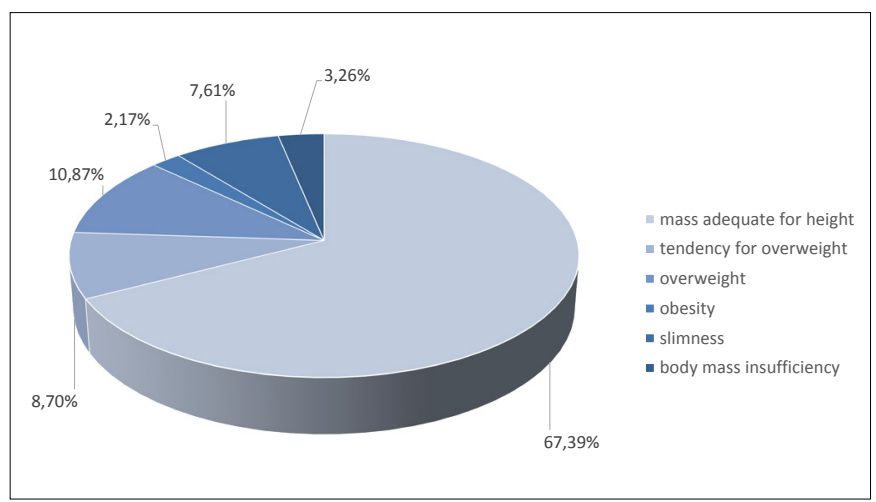

FIGURE 1. Analysis of body mass and height of children.
Mothers exclusively breastfed children for 1 month constituted $9 \%$ of respondents, for 2 months $-8 \%$, for 3 months $-14-16 \%$, for 4 months $-8 \%$, for 6 months -21 that is $25 \%$, for 7 months -2 women $-2 \%$, for 8 months 5 persons $-6 \%$, for 12 months $1-1 \%$, for 14 months $2-2 \%$, for 15 months $1-1 \%$, for 18 months $3-3 \%$, for 24 months $1-1 \%$, the remaining 4\% relied only on artificial milk from birth. Modified milk was introduced: from birth $(9-9.80 \%)$, from 2 nd month (11-12\%), after 3-4 months of life (26-28.30\%), after 5-6 months (30-32.60\%), after 7-8 months of life (7-7.60\%), after 9-10 months $(8-8.70 \%)$. As the most common cause of the introduction of milk mixtures to the mother's diet, the mothers reported inadequate or no food $(52.90 \%)$ and the need to return to work $(29.90 \%)$. The first most frequent parental supplement meal with consistency consisted of gluten and/or gluten-free meal $(71.40 \%)$ and vegetable soup $(47.60 \%)$, and tea or fruit juice $(61.90 \%)$ (Figure 2).

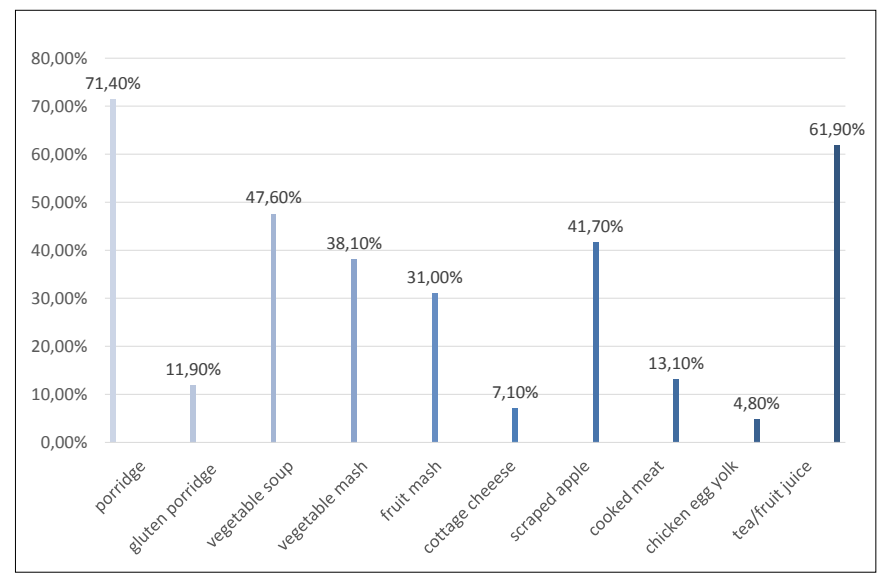

FIGURE 2. Type of food products to be introduced to the child's diet.

Mothers started feeding supplements to the child's diet most often from $4^{\text {th }}$ month of age (30 mothers $\left.-32.60 \%\right)$, $5^{\text {th }}$ month $(25-27.20 \%), 6^{\text {th }}$ month $(23-25 \%), 7^{\text {th }}$ month $(14-15.20 \%)$ (Table 1).

TABLE 1. Time after which mothers start feeding children with the first supplementary food.

\begin{tabular}{lccc}
$\begin{array}{c}\text { The month of a child after which supplementary } \\
\text { food is introduced to him/her }\end{array}$ & Mean & $\mathrm{N}$ & $\begin{array}{c}\text { Standard } \\
\text { Deviation }\end{array}$ \\
\hline $4^{\text {th }}$ month & 33.1333 & 30 & 10.79506 \\
\hline $5^{\text {th }}$ month & 30.4000 & 25 & 11.90238 \\
\hline $6^{\text {th }}$ month & 39.0000 & 23 & 8.74383 \\
\hline $7^{\text {th }}$ month & 33.0714 & 14 & 10.58638 \\
\hline Total & 33.8478 & 92 & 10.91922 \\
\hline
\end{tabular}

Mothers most often introduced gluten-free foods to the child's diet in its 5-6 month of life (35 mothers - 38\%), in 7-9 month $(28-30.40 \%)$ and in the $4^{\text {th }}$ month $(21-22.80 \%)$. Most gluten was introduced to the baby's diet at its 10-12 months of age. There were 19 women who did not give gluten in the first year of life and they constituted $80 \%$ of the respondents. Mothers started to give teas and fruit juices before $4^{\text {th }}$ month of age $(33-35.90 \%)$, in $4^{\text {th }}$ month $(23-25 \%)$, in 5-6 months $(27-29.30 \%)$, in $7-9$ months $(8-8.70 \%)$, one person in 10-12 months of life of the child. The first supplementary meal in the form of vegetable soup or vegetable mash was introduced to the infant diet most often in the 5-6 months of life $(48-52.20 \%)$, in $4^{\text {th }}$ month $(22-23.90 \%)$ and in $7-9$ months 
$(17-18.50 \%)$. Vegetable soup or vegetable mash were given to children in a period of 4 months before birth (4 that is $4.30 \%)$. Chicken egg yolk was introduced to the infant diet in $7-9$ months $(50-54.30 \%)$, in $10-12$ months $(25-27.20 \%)$ in 5-6 months $(13-14.10 \%)$. One person at 4 months of age, two mothers, did not give yolk until 1 year of age. Boiled meat was introduced to the infant diet in 7-9 months of age (47 mothers $-51.10 \%)$, in $10-12$ months $(25-27.20 \%)$ in 5-6 months $(16-17.40 \%)$ and in 4 th month of life $(3-3.30 \%)$. The studied children received mostly cottage cheese in 10-12 months $(\mathrm{n}=49-53.3 \%)$ and in $7-9$ months $(\mathrm{n}=20-21.7 \%)$. More than $10 \%$ of the surveyed mothers did not give their children cottage cheese in their first year of life. Analyzing the introduction of supplementary products to the child's diet depending on their age, indicated the statistical significance of the mean in relation to initiation of administration: egg yolk and cooked meat whereas no statistical significance in the introduction of gluten-free and gluten-free foods, tea or fruit juice, vegetable soup or vegetable or cottage cheese. Below there is the time taken to introduce some supplementary products in the baby's diet until the first year of life (Table 2).

TABLE 2. Time in which some supplementary products other than milk are introduced until 1 year of child's age.

\begin{tabular}{|c|c|c|c|c|c|c|}
\hline \multirow{2}{*}{ Product } & $\begin{array}{c}\text { Before } \\
4^{\text {th }} \text { month }\end{array}$ & $\begin{array}{c}4^{\text {th }} \\
\text { month }\end{array}$ & $\begin{array}{l}5-6^{\text {th }} \\
\text { month }\end{array}$ & $\begin{array}{l}7-9^{\text {th }} \\
\text { month }\end{array}$ & $\begin{array}{l}10-12^{\text {th }} \\
\text { month }\end{array}$ & $\begin{array}{l}\text { Not } \\
\text { given }\end{array}$ \\
\hline & \multicolumn{6}{|c|}{ The number of replies / percent (\%) } \\
\hline $\begin{array}{l}\text { Non-gluten } \\
\text { foods }\end{array}$ & 0 & $\begin{array}{c}21 \\
(22.8 \%)\end{array}$ & $\begin{array}{c}35 \\
(38 \%)\end{array}$ & $\begin{array}{c}28 \\
(30.4 \%)\end{array}$ & $\begin{array}{c}2 \\
(2.2 \%)\end{array}$ & $\begin{array}{c}6 \\
(6.5 \%)\end{array}$ \\
\hline Gluten foods & 0 & $\begin{array}{c}1 \\
(1.1 \%)\end{array}$ & $\begin{array}{c}15 \\
(16.3 \%)\end{array}$ & $\begin{array}{c}18 \\
(19.6 \%)\end{array}$ & $\begin{array}{c}39 \\
(42.4 \%)\end{array}$ & $\begin{array}{c}17 \\
(18.5 \%)\end{array}$ \\
\hline Tea/fruit juice & $\begin{array}{c}33 \\
(35.9 \%)\end{array}$ & $\begin{array}{c}23 \\
(25.0 \%)\end{array}$ & $\begin{array}{c}27 \\
(29.3 \%)\end{array}$ & $\begin{array}{c}8 \\
(8.7 \%)\end{array}$ & $\begin{array}{c}1 \\
(1.1 \%)\end{array}$ & 0 \\
\hline $\begin{array}{l}\text { Vegetable soup } \\
\text { /vegetable mash }\end{array}$ & $\begin{array}{c}4 \\
(4.3 \%)\end{array}$ & $\begin{array}{c}22 \\
(23.9 \%)\end{array}$ & $\begin{array}{c}48 \\
(52.2 \%)\end{array}$ & $\begin{array}{c}17 \\
(18.5 \%)\end{array}$ & $\begin{array}{c}1 \\
(1.1 \%)\end{array}$ & 0 \\
\hline $\begin{array}{l}\text { Chicken egg } \\
\text { yolk }\end{array}$ & 0 & $\begin{array}{c}1 \\
(1.1 \%)\end{array}$ & $\begin{array}{c}13 \\
(14.1 \%)\end{array}$ & $\begin{array}{c}50 \\
(54.3 \%)\end{array}$ & $\begin{array}{c}25 \\
(27.2 \%)\end{array}$ & $\begin{array}{c}2 \\
(2.2 \%)\end{array}$ \\
\hline Cooked meat & 0 & $\begin{array}{c}3 \\
(3.3 \%)\end{array}$ & $\begin{array}{c}16 \\
(17.4 \%)\end{array}$ & $\begin{array}{c}47 \\
(51.1 \%)\end{array}$ & $\begin{array}{c}25 \\
(27.2 \%)\end{array}$ & 0 \\
\hline Cottage cheese & 0 & 0 & $\begin{array}{c}12 \\
(13.0 \%)\end{array}$ & $\begin{array}{c}20 \\
(21.7 \%)\end{array}$ & $\begin{array}{c}49 \\
(53.3 \%)\end{array}$ & $\begin{array}{c}10 \\
(10.9 \%)\end{array}$ \\
\hline
\end{tabular}

Allergies in different forms concerned $25 \%$ of the examined children and mothers associated symptoms with different foods. The statistical analysis did not show the relationship between the natural feeding time of the baby and the occurrence of allergic symptoms in children. Atopic children have the following symptoms: skin rash $(70.60 \%)$, erythema on the cheeks $(23.50 \%)$, atopic eczema $(17.60 \%)$, cough $(11.80 \%)$, conjunctivitis $(8.80 \%)$ diarrhea $(11.80 \%)$ or other food intolerance $(20.60 \%)$. The main food causing allergy in children was cow's milk $(75 \%)$ and cheese preparations $(20.80 \%)$, followed by eggs $(12.50 \%)$, honey $(8.30 \%)$, chocolate $(8.30 \%)$, nuts $(8.30 \%)$ and fish $(4.20 \%)$. Allergy products from the group of fruits and vegetables are: citrus $(16.70 \%)$, tomatoes $(8.30 \%)$, strawberries $(4.20 \%)$, apples $(4.20 \%)$, corn $(4.20 \%)$ and celery (4.20\%) (Figure 3).

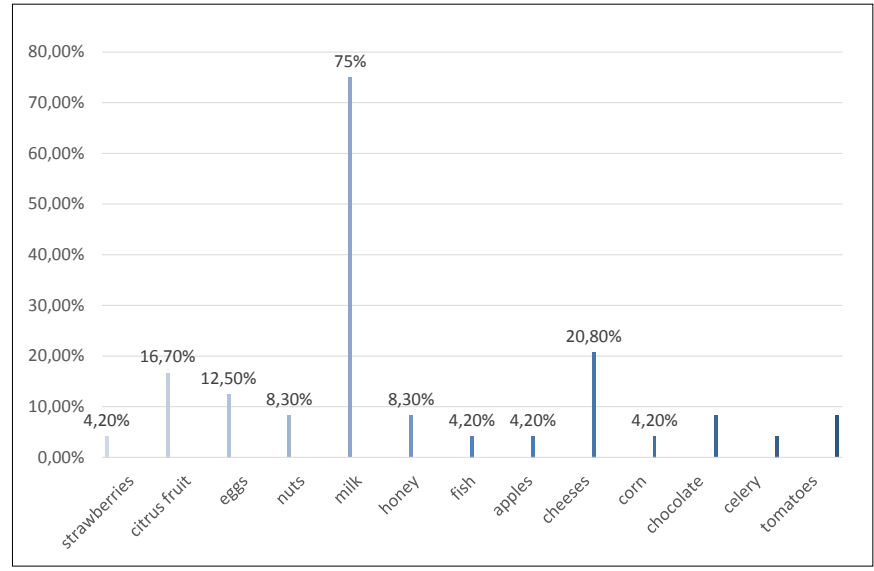

FIGURE 3. Type of food products to be introduced to the child's diet.

In the first year of life, the introduction of fish to the child's diet is declared by over half of the respondents $(48-58 \%)$. Most mothers (about $75 \%$ of the respondents) used ready-toeat baby foods - most often several times a week ( 23 persons or $25 \%)$ or several times a month $(23-25 \%)$. Daily $7.60 \%$ of mothers used ready meals for babies. Self-catering meals are prepared by $25 \%$ of mothers.

\section{DISCUSSION}

Infants are the group which is at most risk of eating disorders. Constant nutritional abnormalities occurring both qualitatively and quantitatively during periods of intensive growth may exert a negative impact on the further psychosomatic development of the organism. Proper nutrition is to provide appropriate energy and building components and to adapt the food to the needs of the growing body. The concept of a correct diet should be understood both to prevent the deficiency of basic nutrients, vitamins and trace elements, as well as the excess of the products to be consumed. Delivery of high-calorie meals may lead to obesity, diabetes or cardiovascular disease in adulthood [5,6]. The early feeding pattern of the baby has a strong influence on the later feeding habits of the toddler [7]. The most common mistakes result from too short breastfeeding, replacing milk with cow milk, overdosing and overdrying foods, providing too little fats in meals, too late serving of meat and fish, or abnormalities in fluid supply [5,8]. Most of the respondents $(84.8 \%)$ declare that they know and use in practice the current pattern of feeding infants in the first year of life. By feeding their children, $67.40 \%$ of the respondents apply both to quantitative and qualitative rules, $15.20 \%$ to qualitative ones, one person only to quantitative ones $(16.30 \%$ of respondents did not answer). Despite the subjective very good self-esteem of mothers concerning knowledge of the current infant formula, the research shows that the nutrition used in practice did not match the nutritional requirements in force.

Constant weight gain and normal psychomotor development in the individual months of the child's life are key indicators of proper nutritional status [9]. In the studied population, normal weight was found in $67.39 \%$ of children, while in the broader standard also included children with tendency to overweight $(8.70 \%)$ and underweight $(7.61 \%)$. Abnormal body weight was diagnosed in $16.31 \%$ of children - including overweight $(8.70 \%)$, obesity $(2.17 \%)$ and weight loss $(3.26 \%)$. By analyzing the above measurements, it is more likely that the abnormal weight of the body was overweight or obese, which may 
be due to inappropriate selection of high calorie products or overfeeding of children. Obesity diagnosed during early childhood constitutes the main cause of the development of this disease and the complications associated with it in adulthood. As the study points out, obese children remain obese at a later stage of life, with the majority of obese adults suffering from childhood obesity. The consequences of overweight or obesity in early child development may result in pulmonological, orthopedic, endocrine, cardiological and other psychosocial problems $[10,11]$. Among the main factors leading to overweight in children are the eating habits of the family. Some of them are listed: feeding delays, delays in introducing chewing foods, feeding and product quality errors, feeding as a teat or reward, tolerance of food whips specifically for sweets, lack of variety rare fruit and vegetable consumption and premature feeding of children with digestible food $[10,11]$. Not only the excess of food, but also their deficiency can adversely affect the child's health, including its resistance. Accepted food not only due to qualitative composition, but also energy properties has a significant impact on the immune function of the body. This is due to the high sensitivity of lymphoid tissue to food deficiencies, where malnutrition results in atrophy of the thymus, decrease in total lymphocyte count, as well as auxiliary and suppressive lymphocytes. Malnutrition in infancy and early childhood may be related to the rate of further weight gain [12].

The most common causes of malnutrition in young children include food hypersensitivity, which should be diagnosed as soon as possible and treated by a temporary or permanent introduction of an elimination diet. Treatment with an elimination diet poses the risk of malnutrition in children, which is associated with improper diet balance or non-compliance with dietary principles. Other studies have shown that nearly $27 \%$ of children treated with anti-diarrheal diet have shown malnutrition, and nutritional disorders were the greatest among children under 1 year of age [13]. Natural feeding for the first 6 months of a child's life fully satisfies his or her nutritional needs, and with sufficient amounts of female food, no fluid is required. Variety of diets in the second half of the year is of great importance for the correct development of reflexes such as biting, chewing and swallowing of solid foods and is due to increasing qualitative and quantitative needs of young children. The gradual introduction of new solid foods allows you to capture ingredients that cause allergy or food intolerance [9]. In the study group, more than half of mothers (57\%) naturally fed their children too shortly, some only one, two or three months, and 4\%.(do czego odnosi się ta liczba?) According to the studies conducted, the decision to introduce supplementary food was mainly the result of parents/carers initiative $(54.30 \%)$ or was taken according to pediatrician's recommendations $(45.70 \%)$.

Often the reason for discontinuing natural feeding is food intolerance that occurs in the baby. It should be borne in mind that diarrhea that usually manifests in intestinal colic in infants does not affect women's milk but is more likely to be due to the presence of exogenous proteins derived from the mother's diet. Eliminating certain products eaten by the mother often alleviates symptoms in the baby [14].

Natural and artificial feeding are not equivalent as evidenced by the results of many scientific studies on the effects of feeding the children on their subsequent physical and psychomotor development. According to Łoś-Rycharska et al., children aged 18 months breastfed and fed with modified milk exhibited different dynamics of weight gain depending on the type of diet [15]. Infants who were fed naturally gained overweight or obesity compared to their peers who were artificially fed less weight gain until they reached pre-school age, but they were more likely to suffer from weight loss [16]. The measurable health benefits of natural feeding are also due to the lower propensity of children for systemic infections, respiratory and digestive diseases, or the incidence of autoimmune and inflammatory diseases $[17,18]$. Milk and its products are of the highest nutritional value, providing a good source of protein and calcium, potassium and magnesium, $\mathrm{B}$ vitamins and fat soluble vitamins (A, D, E). Calcium contained in milk cannot be replaced by other ingredients, as is possible in the case of e.g. protein, fats or vitamins [19]. On the basis of the study, it can be concluded that mothers too early introduced dairy mixes to the child's diet, which could have resulted in abnormal lactation, persistence of improper taste preferences, or infant habits. The statistical analysis did not show the relationship between the age of the child and the time when milk mixtures were started. Milk mixtures can only be introduced when a mother with reasonably legitimate causes cannot breastfeed. Cow's milk should not be given to children before the age of 12 months due to its poor biochemical composition and insufficient iron, which may cause deficiency anemia $[18,20,21]$. In infants who are breast-fed, iron stores are already exhausted by about 4-6 months of age, so supplementation with this micronutrient has been a good practice $[8,20,21]$.

Contemporary dairy modifications include prebiotics - non digestive nutrients that mobilize growth and activity of bacteria in the large intestine to prevent colonization by the pathogenic bacteria. The beneficial effect of prebiotics is probably related to the prevention of infectious and allergic diseases [8,12,20,22-24].

In the studied group, $25 \%$ of children demonstrated allergic symptoms, while milk, despite being the most nutritious product in the infant diet, was the most frequently mentioned as allergy product. For food allergy, it is most often found in young children, because during this period the immune system is exposed to many allergens during this period [24]. The most common cause of allergy among young children is allergy to cow's milk protein. One treatment is to use an elimination diet to prevent allergy symptoms. A common problem is lactose intolerance, which is badly absorbed by the baby's body. Mothers should not, however, abstain from giving it too soon unless medically documented for contraindications. In the case of lactose intolerance, administration of free or low-lactose milk is recommended [19].

In the study group the most often mentioned products causing allergy symptoms apart from milk and its products were eggs, honey, chocolate, fish, fruit and vegetables i.e. citrus, strawberries, apples, tomatoes, corn or celery. According to current medical knowledge, there is no scientific evidence that avoiding or delaying the introduction of potentially sensitizing foods reduces the incidence of allergy in all infants weighed or not at risk $[18,19,24,25]$.The child's diet in solid foods can be expanded no sooner than in the fourth and no later than in the sixth month of the its life. Too fast introduction of them may adversely affect physiological processes, including digestion and food absorption, posing an increased risk of food allergy [24]. In the current feeding pattern of breastfed infants it is recommended to breastfeed on demand in the first half of the year 
and to introduce no more than 5 months of age gluten-free vegetable soup and in the second half of the year, feeding on demand and gradually introducing complementary meals. [27,28].

Feeding infant artificially is recommended for the first six months of initial milk and in the second half of the following supplementary food for 5 months, i.e. gluten free mashes, fruits and vegetables, and for 6 months vegetable soups, initially with a small amount of gluten [27]. The basis of the supplementary baby food is vegetable soup, prepared on the basis of vegetables such as potatoes, carrots, parsley, cauliflower, beetroot, pumpkin or kohlrabi. Soups should be enriched with highquality butter, olive oil or low-sugar rapeseed oil plus 2-3 g manna for $100 \mathrm{ml}[26,27]$.

In the study group, some mothers introduced soup or vegetable mash before the fourth month of life, while over $35 \%$ were giving children tea or fruit juices, which could have resulted in too much sugar intake and weight gain. It is recommended that gluten-containing products are introduced in the fifth and no later than in the sixth month of the child's life [9] in the current feeding plan for celiac disease prevention. Only $16(30 \%)$ of mothers fed gluten foods in accordance with the rules of nutrition and usually around 1 year of age.

According to the feeding pattern of breastfed infants and artificial feeding, half of egg yolk is introduced as a supplement to vegetable mash, initially every other day from the 7th month of the child's life, later, all day yolk [8,9,25-27]. Chicken egg yolk incorporated into the infant diet in addition to its building value is a source of micronutrients (i.e. iron, iodine), vitamins (groups A, D, E, B1, B5, B12, folic acid) and unsaturated fatty acids [26,27]. More than half of the mothers administered yolks to children in 7-9 months (50 mothers $-54.30 \%$ ). Abnormalities involved too early or too late introduction of yolks i.e. 5-6 months $(14.10 \%)$ or $10-12$ months (25 that is $27.20 \%$ ). Two people did not recognize the proper administration of egg yolk in the first year of life of the child. Meat cooked without decoction can be administered to children artificially fed in the sixth month of life, and fed naturally one month later, paying attention to the fact that the consistency of the food should stimulate the chewing reflex. Introduction of meat foods, initially in small quantities and without decanting, provides adequate supply of protein, iron, vitamins Group B and Carnitine [8,9,25-28].

In the study group, the abnormalities in the introduction of meat products resulted mainly from their too late supply (1012 months, $27.20 \%$ ). It is disturbing that some mothers served cooked meat at the age of 4 months, which may have exaggerated the immature body of the toddler. According to the current dietary recommendations cheese curd should not be introduced into the diet of children before 11 months of their lives $[8,9,25-28]$. In the study group, cottage cheese as a meal was given too early for 5-6 months (13\%) or 7-9 months $(21.70 \%)$, while over $10 \%$ of children did not receive cheeses in the first year of life. Fish products should be fed to infants fed naturally from 7 months and fed artificially from 6 months [8,9,25-28]. Omega 3 intake in the study population was $43 \%$ of children; the remaining $57 \%$ of the respondents did not declare dietary supplementation. Nearly half of mothers in the first year of life do not even give fish products to their children.

In order to ensure the correct development of the child during the life-cycle, it is important not only to control the choice of food intake in terms of quantity and quality according to the age-adjusted diet regimen, but also to evaluate the nutritional status of anthropometric measurements or biochemical indicators as needed. Diagnosis should complement the assessment of the child's behavior, appetite, physical activity, or well-being [1]. Nutrition education conducted at various levels of academic education (physicians, nurses, dieticians), medical practice or consumer level (parents/carers) should take into account information on nutrients that influence growth and development of the body, baby and current patterns of proper nutrition. It is therefore important to show the relationship between lifestyle and health, and to shape and maintain proper eating habits. [1]

\section{CONCLUSIONS}

1. Evaluating the nutritional status of the examined children was found to be more prevalent in overweight and obesity than in weight loss.

2. The introduction of complementary foods to the infant diet largely did not match the current nutritional guidelines for 2007.

3. Mothers too shortly nourished children naturally and too early in the introduction of milk mixtures to the infant diet.

4. As many as $25 \%$ of the tested children demonstrated allergy symptoms, and the most commonly mentioned allergy product was milk.

5. Most mothers preparing food for children used ready-to-eat baby foods.

6. On the basis of the results obtained, it may be concluded that there is a need to intensify preventive measures for the proper feeding of infants by health workers.

\section{REFERENCES}

1. Socha J. Żywienie, a rozwój dziecka w pierwszym roku życia. Nowa Pediatr. 2002;2(29):96-102.

2. Matusik P, Małecka-Tendera E, Nowak A. Metody stosowane w praktyce pediatrycznej do oceny stopnia odżywienia dzieci. Endokrynol Otyłość. 2005;2(1):6-11.

3. Palczewska I, Szilagyi-Pągowska I. ABC zabiegów diagnostycznych i leczniczych w pediatrii. Ocena rozwoju somatycznego dzieci i młodzieży. Med Prakt Pediatr. 2002;3(21):140-6.

4. Szilagyi-Pągowska I. Auksjologia. Medycyna Praktyczna Pediatria.2002;2(20):127-38.

5. Gnyś I. Najczęstsze błędy żywieniowe. In: M. Krawczyński (ed). Żywienie dzieci w zdrowiu i chorobie. Kraków: Wydawnictwo HELPMED; 2008. p. 61-2.

6. Jopkiewicz A, Suliga E. Biomedyczne podstawy rozwoju i wychowania. Radom: Wyd. Naukowe, Instytut Eksploatacji-Państwowy Instytut Badawczy; 2008. p. 47-50.

7. Łoś-Rycharska E, Niecławska A. Wpływ wybranych elementów żywienia dzieci w wieku niemowlęcym na wybrane cechy ich żywienia w okresie poniemowlęcym i przedszkolnym. Pediatr Współcz. 2010;12:2.

8. Socha J, Socha P, Weker H. Żywienie dzieci, a zdrowie wczoraj, dziś i jutro. Pediatr Współcz. 2010;12(1):34-7.

9. Czerwionka-Szaflarska M. Karmienie dzieci w poszczególnych okresach życia. In.: B. Pawlaczyk. Pielęgniarstwo pediatryczne. (ed). Warszawa: PZWL; 2012. p. 49-63.

10. Schneider MB, Brill SR. Otyłość u dzieci i młodzieży. Pediatr Dypl. 2006; 10(3):38-45.

11. Kardasz M, Pawłowska D. Wpływ otyłości w dzieciństwie na przyszłe życie człowieka dorosłego. Nowa Pediatr. 2008;2:35-40.

12. Książyk J. Żywienie, a odporność. Nowa Pediatr. 2002;3(30):204-8.

13. Adamska I, Świątek K, Czerwionka-Szaflarska M. Wpływ eliminacyjnej diety bezmlecznej na stan odżywienia dzieci do ukończenia drugiego roku życia. Pediatr Współcz. 2007; 9:1. 
14. Gnyś I. Karmienie naturalne (piersią) noworodka i niemowlęcia. In: M. Krawczyński. (ed). Żywienie dzieci w zdrowiu i chorobie. Kraków: Wydawnictwo HELPMED; 2008. p. 72-82.

15. Łoś-Rycharska E, Adamska I, Swincow G. Średnia masa ciała dzieci w wieku do 18 miesiąca życia karmionych naturalnie i mlekiem modyfikowanym. Wiad Lek. 2006;LIX:5-6.

16. Łoś-Rycharska E, Kiejdo P, Czerwionka-Szaflarska M. Wpływ sposobu żywienia dzieci w wieku niemowlęcym na masę ich ciała w wieku przedszkolnym. Pol Merkuriusz Lek. 2007;XXII:130, 263.

17. Kowalewska-Kantecka B. Karmienie pokarmem matki złotym standardem żywienia noworodków i niemowląt. Pediatr Współcz. 2007;9(1):65-8.

18. Horvath A, Dziechciarz P. Żywienie dziecka w 1. roku życia. Stand Med Pediatr. 2010:563-6.

19. Cichy W. Mleko, jako najwartościowszy produkt spożywczy. In: M. Krawczyński (ed). Żywienie dzieci w zdrowiu i chorobie. Kraków: Wydawnictwo HELPMED; 2008. p. 24-29.

20. Szajewska H, Albrecht P, Dziechciarz P, Horvath A. Postępy w gastroenterologii i żywieniu dzieci w 2007 roku. Med Prakt Pediatr.2008;2 (56):5164.

21. Borgna-Pignatti C, Marsella M. Pediatric Annals. Niedobór żelaza u niemowląt i dzieci. Med Prakt Pediatr. 2009;3(63):51-63.
22. Gnyś I, Piątkowska P. Probiotyki i prebiotyki w żywieniu dzieci i młodzieży. In.: M. Krawczyński (ed). Żywienie dzieci w zdrowiu i chorobie. Kraków: Wydawnictwo HELPMED; 2008. p. 53-9..

23. Agostoni C, Axelsson I, Braegger C. Bakterie probiotyczne w produktach żywieniowych dla niemowląt. Komentarz Komitetu Żywienia Towarzystwa Gastroenterologii, Hepatologii i Żywienia Dzieci ESPGHAN. Med Prakt Pediatr. 2004;4(34):39-52 .

24. Adamska I, Czerwionka-Szaflarska M. Profilaktyka alergii pokarmowej u dzieci. Stand Med Pediatr. 2010;7:580-9.

25. Agostini C, Decsi T, Fewtrell M. Wprowadzanie pokarmów uzupełniających. Komentarz Komitetu ESPGHAN ds. Żywienia. Med Prakt Pediatr. 2008;3(57):45- 61.

26. Cichy W. Wprowadzanie tzw. pokarmów stałych. In: M. Krawczyński (ed). Żywienie dzieci w zdrowiu i chorobie. Kraków: Wydawnictwo HELPMED; 2008. p. 91-4.

27. Aktualne wytyczne w pediatrii. Zalecenia dotyczące żywienia dzieci zdrowych w pierwszym roku życia opracowane przez zespół ekspertów powołany przez konsultanta krajowego w dziedzinie pediatrii. Pediatr Dypl. Wyd. specjalne. 2008:8-15.

28. Książyk JB, Weker H.: Nowe zalecenia żywienia niemowląt w Polsce od roku 2007. Pediatr Współcz. 2007;9(4):292-7.

Corresponding author

Aneta Mielnik

6 Pogodna Str.,38-500 Sanok

E-mail: a.mielnik@op.pl

tel: 723521220 